\title{
REFLEKSI: PENDEKATAN UNTUK MENINGKATKAN PROFESIONAL DALAM PRAKTIK MENGAJAR
}

\author{
Rina Wahyuni \\ STKIP Tunas Palapa \\ E-mail: rhyna93.rw@gmail.com
}

\begin{abstract}
Abstrak.
Tujuan dari penelitian ini adalah untuk mengetahui sejauh mana pengajaran reflektif dapat menjadi strategi pengembangan profesional pengajaran bahasa. Praktik mengajar reflektif membantu dosen untuk merencanakan, melaksanakan dan meningkatkan kinerjanya dengan memikirkan kembali kekuatan dan kelemahannya. Populasi penelitian ini adalah seluruh dosen Jurusan Bahasa Inggris STKIP Tunas Palapa. Penelitian kualitatif dilakukan di STKIP Tunas Palapa. Kesimpulan menunjukkan bahwa refleksi merupakan salah satu alternatif untuk meningkatkan kesadaran tentang pengajaran praktik profesional, dan sebagai sarana untuk mendorong dosen membuka pikiran, memperbaharui metode dan strategi pengajaran di kelas.
\end{abstract}

Kata kunci: refleksi, praktik profesional mengajar, pendekatan pengajaran reflektif.

Abstract.

The aim of this study is to determine the extent that reflective teaching can become a strategy for language teaching professional development. Reflective teaching practice helps lecturer to plan, implement and improve their performance by rethinking about their strengths and weaknesses. The population of this research is all of the lecturers in English department of STKIP Tunas Palapa. The qualitative research was conducted in STKIP Tunas Palapa. Conclusions indicated that reflection is an alternative to raise awareness about teaching professional practice, and as a means to push the lecturer to open their minds, renew their teaching method and strategies in the classroom.

Keywords: reflection, teaching professional practices, reflective teaching approach.

\section{PENDAHULUAN}

Pendidikan terus menjadi bagian penting di era ini. Oleh karena itu, pendidikan menjadi jembatan bagi anak-anak untuk menjadi manusia yang baik. Pendidikan dapat menjadi bagian penting di Indonesia karena tingkat pendidikan dapat memberikan pengaruh bagi kehidupan setiap manusia. Pendidikan tidak terlalu jauh dari proses belajar mengajar di kelas. Dalam proses ini, dosen Berperan besar bagi pengetahuan siswa seperti penyampaian materi, bagaimana mengaplikasikan materi yang berhubungan dengan kehidupannya dan memberikan teladan sikap yang baik. Mengajar baru-baru ini ditetapkan sebagai profesi dan dosen sekarang memiliki tanggung jawab yang sama dengan orang lain yang terlibat dalam pekerjaan profesional. Untuk menjadi dosen yang profesional itu tidak mudah, mereka harus menjadi dosen yang kreatif, dosen yang inovatif dan yang terpenting mengetahui apakah yang disampaikan di kelas dapat ditangkap oleh mahasiswa. Salah satunya dengan melihat apakah dosen profesional atau tidak menggunakan refleksi. Refleksi atau pengajaran reflektif merupakan salah satu proses penting dalam pendidikan karena membantu dosen dan pengembangan peserta didik dalam banyak hal seperti pemecahan masalah dan proses pengambilan keputusan. Ini merangsang mereka untuk mengembangkan berbagai keterampilan seperti pengambilan keputusan, bertemu kognisi dan pemikiran logis. Menurut Goodley (2018) Praktik mengajar reflektif merupakan salah satu proses penting dalam 
pendidikan guru. Gheith, E., \& Nahil, A (2018: 163) menyatakan bahwa praktik reflektif dapat digambarkan sebagai proses pemecahan masalah dan rekonstruksi makna, serta penilaian reflektif berikutnya sebagai pengalaman guru dengan kegiatan baru. Pernyataan tersebut didukung oleh Shandomo, HM (2008: 103) Pemikiran reflektif mengarahkan pendidik untuk bertindak dengan sengaja dan sengaja daripada secara acak dan reaktif. Oleh karena itu, pengajaran reflektif adalah proses yang berguna yang mengarah pada pengembangan profesional guru.

Pengajaran reflektif adalah pendekatan inovatif dalam mengajar; ini adalah pendekatan yang berharga di mana guru menggunakan intuisi dan pengalaman mereka untuk mengamati kinerja mereka, mengevaluasi diri mereka sendiri, mengkritik praktik mereka dan menerima kritik lain secara terbuka. Ini membantu mereka untuk maju dan mengembangkan kinerja pengajaran mereka. Situasi ini memaksa guru untuk mendeskripsikan, menganalisis dan mengevaluasi dan menggunakan wawasan yang dihasilkan untuk meningkatkan praktik. Rose (2007: 1) menyatakan bahwa kemitraan reflektif antara guru sangat efektif. Kemitraan mentoring teman sebaya akan mendukung guru individu dalam merefleksikan dan menggambarkan praktik mereka. Hasilnya, seorang guru bisa lebih memahami dan meningkatkan latihan. Setiap guru hendaknya merenungkan apa yang menjadi dasar untuk meningkatkan kualitas pembelajarannya, dengan pendekatan refleksi guru dapat lebih berhasil dan efektif dalam mengajar. Olaya MML (2018: 152) mengemukakan gagasan bahwa guru membutuhkan refleksi untuk mengubah rutinitas sehari-hari di dalam kelas. Sudah umum untuk mengenali bahwa guru cenderung menerapkan metode pengajaran, mungkin karena keyakinan mengajar mereka atau kurangnya pengembangan profesional. Menimbang apa yang dikatakan sebelumnya tentang refleksi dan melihat apa pentingnya dengan melakukan refleksi, dalam penelitian ini peneliti ingin mengetahui apakah dosen di STKIP Tunas Palapa menerapkan refleksi atau tidak. Jika mereka melakukan refleksi seperti apa yang mereka gunakan untuk meningkatkan profesionalisme mereka dalam mengajar.

\section{METODE PENELITIAN}

Desain penelitian ini adalah penelitian kualitatif. Peneliti menggunakan deskriptif kualitatif sebagai metode penelitian. Penelitian ini disebut sebagai penelitian kualitatif karena berhubungan dengan fenomena alam. Subroto (2007: 5) mengartikan metode kualitatif sebagai metode yang digunakan untuk menganalisis masalah-masalah yang tidak dirancang atau disusun dengan menggunakan prosedur statistik. Penelitian kualitatif yang menitikberatkan pada pemahaman fenomena sosial dari sudut pandang para peserta penelitian. Gay $(2000 ; 275)$ menjelaskan bahwa metode deskriptif berguna untuk menyelidiki berbagai masalah dan isu pendidikan. Penelitian kualitatif deskriptif merupakan penelitian yang dianggap dapat memperoleh informasi tentang fenomena tersebut. Moelong (2006: 5) menunjukkan bahwa penelitian deskriptif adalah suatu metode penelitian yang berusaha menggambarkan dan menginterpretasikan objek sebagaimana adanya. Secara singkat, dalam penelitian deskriptif ini ditunjukkan tujuan penerapan refleksi di STKIP Tunas Palapa.

Partisipan dalam penelitian ini adalah dosen Bahasa Inggris STKIP Tunas Palapa. Ada 7 dosen dewasa. Sebelum melakukan penelitian, peneliti menanyakan kepada dosen tentang kesediaannya 
mengikuti penelitian selanjutnya dan menjelaskan secara singkat tujuan penelitian. Para dosen pun diyakinkan bahwa data akan dijaga kerahasiaannya.

\section{a. Teknik Pengumpulan Data}

Untuk menjawab pertanyaan penelitian, peneliti menggunakan dua jenis materi, yaitu observasi mengajar reflektif dan wawancara.

a) Observasi

DeWALT \& DeWALT (2002: 54) mengemukakan bahwa langkah-langkah yang digunakan dalam penelitian ini adalah:

1. Mengamati secara aktif, memperhatikan detail yang ingin dicatat kemudian.

2. Perhatikan interaksi yang terjadi di lokasi, termasuk siapa yang berbicara dengan siapa, pendapat siapa yang dihormati, bagaimana keputusan dibuat.

3. Menghitung orang atau insiden aktivitas yang diamati berguna dalam membantu seseorang mengingat kembali situasi, terutama saat melihat peristiwa atau peristiwa kompleks di mana terdapat banyak peserta.

4. Dengarkan baik-baik percakapan, cobalah mengingat percakapan kata demi kata, ekspresi nonverbal, dan gerak tubuh sebanyak mungkin. Untuk membantu melihat peristiwa dengan "pandangan baru", ubah catatan mendetail menjadi catatan lapangan yang ekstensif, termasuk peta spasial dan peta interaksi. Perhatikan baik-baik untuk mencari wawasan baru.

5. Buat catatan observasi.

b) Wawancara

Ballard, KK (2006: 26) menyiapkan lima daftar pertanyaan wawancara untuk mengetahui refleksi guru dalam proses mengajar. Pertanyaan-pertanyaan tersebut menjadi kerangka wawancara dalam penelitian ini. Berikut adalah daftar pertanyaan wawancara.

1. Apakah menurut Anda pembelajaran itu berhasil? Mengapa / Mengapa tidak?

2. Apa, jika ada, yang akan Anda ubah tentang pembelajaran ini?

3. Apa manfaat yang sangat penting dari pembelajaran ini?

4. Dapatkah Anda memikirkan metode lain yang mungkin Anda gunakan untuk melaksanakan pembelajaran itu?

5. Apakah menurut Anda materi yang dibahas penting bagi mahasiswa? Mengapa / Mengapa tidak?

Diadopsi dari Ballard, KK (2006: 26)

\section{HASIL DAN PEMBAHASAN}

Hasil data penelitian ini menunjukkan bahwa para dosen di STKIP Tunas Palapa telah melakukan refleksi dalam proses belajar mengajar. Temuan tersebut mengungkapkan bahwa para dosen cukup sadar akan manfaat yang signifikan dari praktik refleksi. Refleksi berperan penting dalam program pendidikan, karena refleksi membantu guru dalam menyelesaikan masalah yang dihadapi di kelas. Ini membantu mereka mengevaluasi pekerjaan mereka selama aktivitas mereka di kelas. Ambady, KG (2018: 9) refleksi juga secara mendasar menciptakan perbaikan dalam praktik pendidikan, dan hubungan sosial yang mendasari praktik tersebut. Ambady, KG (2018: 9) dalam jurnalnya juga mendukung refleksi sebagai bagian penting dalam pengajaran. Ini sebagai dasar peningkatan pendidikan dalam hubungan antara praktek belajar mengajar. Ferdowsi, M. \& Afghari, A. (2015: 21) mengatakan bahwa pengajaran reflektif adalah salah satu proses penting dalam pendidikan karena membantu perkembangan guru dan peserta didik dalam banyak hal seperti pemecahan masalah dan proses pengambilan keputusan serta menumbuhkan pemikiran 
kritis. Menurut Artzt, CG \& Thomas (2015: 21) pengajaran reflektif diartikan sebagai proses melihat kembali pengajaran guru itu sendiri. Ini termasuk berpikir dan memikirkan kembali tentang kinerja seseorang sebelum, selama dan setelah kegiatan kelas. Instruktur harus merefleksikan masalah siswa yang mungkin terjadi selama pencapaian tujuan yang ditargetkan. Guru harus merenungkan tentang strategi pengajaran yang perlu mereka pertimbangkan dalam menyampaikan pelajaran yang diharapkan. Jadi refleksi dapat diartikan sebagai proses merefleksikan diri dalam mengajar termasuk berpikir dan memikirkan kembali kinerjanya dalam proses belajar mengajar. Ferdowsi, M. \& Afghari, A. (2015: 21) dosen merefleksikan permasalahan mahasiswa selama proses pembelajaran. Guru mungkin memulai proses refleksi dalam situasi yang berbeda, mereka mungkin berkonsentrasi untuk merefleksikan masalah tertentu di kelas atau untuk menyelidiki keefektifan pengajaran mereka pada poin tertentu. Mengingat apa yang dikatakan di atas, berarti refleksi kemungkinan besar bagaimana dosen menilai diri sendiri, mengamati kinerja di kelas, mengkritisi praktik di kelas dan memiliki karakter berpikiran terbuka terhadap kinerjanya di kelas. Ini akan membantu para dosen mengembangkan dan meningkatkan kinerja mereka dalam pengembangan profesional.

Mathew, P., Mathew, P. \& Prince, JP (2017: 127) Pengajaran reflektif adalah proses di mana guru memikirkan praktik pengajaran mereka, menganalisis bagaimana sesuatu diajarkan dan bagaimana praktik tersebut dapat ditingkatkan atau dimodifikasi untuk hasil pembelajaran yang lebih baik. Penting bagi guru profesional untuk mencoba mengevaluasi seberapa sukses suatu kegiatan dalam kaitannya dengan keterlibatan siswa dan hasil belajar (Harmer, 2007). Dalam pendidikan menjadi guru yang baik itu penting, apalagi guru berperan besar dalam proses transfer ilmu kepada siswa. Artinya dosen dituntut menjadi guru yang profesional untuk meningkatkan proses belajar mengajar. Oleh karena itu, peningkatan praktik mengajar di bidang pendidikan melalui refleksi menjadikan keputusan yang tepat untuk lebih meluasnya pengembangan profesionalitas dosen. Beberapa hal yang menjadi pertimbangan dalam proses refleksi dapat berupa apa yang sedang dilakukan, mengapa dilakukan dan seberapa baik pembelajaran siswa.

Dengan mengumpulkan informasi tentang apa yang terjadi di kelas, dan menganalisis serta mengevaluasi informasi tersebut, mereka mengidentifikasi dan mengeksplorasi praktik dan keyakinan yang mendasarinya. Refleksi guru berkaitan dengan sikap dosen karena pembicaraan tentang dosen dilakukan di kelas. Gheith, N. (2018: 168) guru 'Sikap terhadap Pengembangan Diri profesional adalah ide, konsepsi, tanggapan, dan sikap mereka tentang kemandirian dalam proses mereka mengembangkan pengetahuan, keterampilan, dan sikap terhadap karir mengajar mereka. Guru juga perlu menggabungkan kreativitas pengajaran dengan menggunakan keragaman metode pembelajaran, teknologi pendidikan atau menawarkan tugas kompleks untuk mempromosikan berbagai jenis interaksi. Misalnya saat dosen menyampaikan materi tentang CCU (Cross Culture Understanding) maka dosen membawa barang berupa gambar, video atau patung. Ada berbagai alasan mengapa baik bagi guru untuk merefleksikan praktik mereka yang dikemukakan oleh Farrell (2015: 25). Misalnya, melalui praktik reflektif, guru mengembangkan teori mereka sendiri tentang pengajaran bahasa Inggris atau mengembangkan teori yang sudah ada. Selain itu, guru membuat berbagai hubungan antara teori dan praktik sambil mengeksplorasi keyakinan mereka sendiri tentang mengajar. Guru juga terlibat dalam praktik pengajaran berbasis bukti, memecahkan masalah melalui inkuiri dan meningkatkan kemanjuran diri dan profesionalisme pengajaran mereka sendiri. Farrel (2015: 25) menyebutkan bahwa praktik reflektif dapat membantu dosen mengembangkan gaya mengajarnya dengan memadukan teori dan metode pengajaran di kelas. Banyak sekali pengaruh menggunakan refleksi dalam penampilan mengajar mereka. Salah satunya 
adalah dosen mengetahui kekurangannya dalam mengajar; itu akan memperbaiki kemanjuran diri dan profesionalisme mereka. Bailey (2012: 30) mengemukakan beberapa keuntungan menggunakan refleksi dalam mengajar yaitu (1) dosen lebih sadar tentang apa yang sebenarnya mereka lakukan di kelas, (2) dosen dapat menggunakan kegiatan berbagi kolegial yang dipromosikan jika data dikumpulkan dalam konteks profesional yang melibatkan guru lain seperti team teaching, (3) dari guru wawasan, dosen melalui refleksi, benar-benar bisa meningkatkan pengajarannya, (4) menambah wawasan dan menambah praktik dosen dapat membantu guru yang berpengalaman mengatasi burnout, (5) menegaskan praktik dosen saat ini dan (6) membantu dosen buat hubungan antara teori dan praktek.

Pelaksanaan refleksi dalam pembelajaran merupakan bagian dari profesi guru. Menurut Gross (2014: 19) refleksi dalam praktik profesional memberikan ruang bagi seorang praktisi untuk menjadi ahli. Refleksi melibatkan pemikiran dan evaluasi hasil praktik, dengan demikian seorang profesional mampu meningkatkan pengetahuan tentang strategi yang berhasil untuk digunakan di masa depan. Praktik reflektif telah menjadi fokus minat dan gerakan yang kuat dalam pendidikan guru dikemukakan oleh Mathew, P., Mathew, P. \& Prince, JP (2017: 126). Refleksi sangat bermanfaat bagi dosen karena memfasilitasi profesionalisme dosen dalam proses belajar mengajar. Mereka dapat menyadari kelemahan mereka selama proses belajar mengajar kemudian akhirnya mengevaluasi kelemahan tersebut agar kinerjanya lebih baik. Mathew, P., Mathew, P. \& Prince, JP (2017: 126) mengatakan bahwa praktik reflektif merupakan alat penting dalam pengaturan pembelajaran profesional berbasis praktik di mana orang belajar dari pengalaman profesional mereka sendiri, bukan dari pembelajaran formal atau transfer pengetahuan. Selain itu, Robichaux dan Guarino (2012) menemukan bahwa dengan membiasakan refleksi, pengabdian dosen adalah meningkatkan kebiasaan tumbuh kembang profesional. Proses ini akan mendorong guru untuk memikirkan kembali tentang penggunaan media dan metode yang tepat dalam menyampaikan materi kepada siswa. Ini akan berlanjut untuk kehidupan masa depan mereka sebagai seorang guru karena refleksi mengajarkan mereka seperti halnya seorang guru profesional dan bagaimana menjadi seorang ahli.

Jay (2003: 1) berpendapat bahwa praktik reflektif didasarkan pada refleksi kritis, juga dijelaskan sebagai proses kontemplasi dengan keterbukaan untuk berubah, kemauan untuk belajar, dan rasa tanggung jawab untuk melakukan yang terbaik. Berdasarkan uraian Jay (2003: 1) refleksi akan menjadi tanggung jawab dosen untuk mempelajari dan mengkritisi kinerjanya selama proses pembelajaran untuk mencapai tujuan pembelajaran. Jenis refleksi ini menggabungkan berpikir, mengetahui, dan melakukan. Para guru memikirkan tentang apa yang mereka lakukan dan bagaimana mereka melakukannya, memanfaatkan pengetahuan praktis yang menjadi dasar pengajaran mereka. Akibatnya, refleksi dalam tindakan menyangkut kemampuan guru untuk menghadapi dilema kelas saat itu terjadi. Tujuan utamanya adalah untuk menanggapi pembelajaran siswa dengan sukses pada saat tertentu. Perlu diperjelas bahwa, secara umum, refleksi terkait dengan kegiatan positif dan negatif yang muncul dalam proses belajar mengajar. Ferdowsi, M. \& Afghari, A. (2015: 20) menyatakan bahwa pendekatan refleksi dalam proses belajar mengajar melibatkan perubahan dari istilah tradisional ke istilah baru dalam proses belajar mengajar. Guru yang menggali keterampilan dan mengembangkan kesadaran melalui refleksi akan memperoleh manfaat bagi peningkatan profesionalitas. Jadi jelas bahwa refleksi dalam proses belajar mengajar sangat membantu guru dalam meningkatkan kinerjanya terutama untuk membangun jalannya menjadi guru yang profesional. Hal tersebut didukung oleh pernyataan Mathew, P., Mathew, P, \& Prince, JP (2017: 128) yang menyatakan bahwa pengajaran reflektif merupakan elemen penting dalam program pelatihan awal mahasiswa sebagai calon guru. Ini juga 
telah diakui secara luas oleh banyak peneliti sebagai pendekatan yang dapat mendorong pengembangan profesional guru dan meningkatkan kualitas pengajaran dan pembelajaran.

Dari uraian diatas, data menunjukkan bahwa dosen melakukan refleksi setelah proses belajar mengajar. Hal ini didukung oleh ungkapan mereka bahwa penggunaan refleksi penting karena refleksi dapat mengevaluasi diri mereka dengan berbagai cara. Tidak hanya dalam proses belajar mengajar, tetapi juga profesionalisme dalam dunia pendidikan. Peneliti mendapatkan data dengan wawancara dan observasi. Dosen melaporkan bahwa penerapan praktik reflektif membantu mereka untuk memilih sekaligus menggunakan metode pengajaran yang berbeda. Mereka mengevaluasi pengajaran mereka dengan melihat respon siswa. Hal ini menuntut mereka untuk berpikir kritis dan kreatif serta memenuhi kebutuhan siswa. Penggunaan berbagai metode dan media dalam mengajar tanpa disadari menuntut mereka untuk membangun profesionalisme dalam mengajar.

\section{KESIMPULAN}

Refleksi dalam mengajar merupakan metode evaluasi diri dalam mengajar; manfaat yang didapat dosen dapat diperoleh dengan menerapkan evaluasi semacam ini. Dosen dapat menjadikan perkuliahan secara inovatif di dalam kelas karena mereka mempertimbangkan berbagai macam sarana untuk melaksanakan proses belajar mengajar. Dosen dapat menggunakan keragaman dan alat yang sesuai dengan kepribadian dan kebutuhannya. Evaluasi yang sering dilakukan ini akan membantu dosen untuk meningkatkan profesionalitasnya dalam mengajar. Penerapan refleksi pada praktik profesionalisme sudah jelas, seperti halnya individu mendeskripsikan, menganalisis dan merencanakan suatu metode untuk meningkatkan aktivitasnya. Pendekatan ini akan meningkatkan praktik pribadi diri.

\section{DAFTAR PUSTAKA}

Ambady KG (2018). Praktik Reflektif dalam Mengajar: Profesi dan Profesionalisme. Departemen Pendidikan, RIE-NCERT, Mysuru.

Artzt, AF, Thomas, EAF, \& Curcio, RG (2015). Menjadi Guru Matematika Reflektif Edisi ke-2 Panduan untuk observasi dan penilaian diri. Lawrence Erlbaum Associates Taylor \& Francis Grup 270. New York: Madison Avenue.

Bailey, KM (2012). Pedagogi Reflektif. Dalam Anne Burns \& Jack C. Richards (Eds.), Panduan Cambridge untuk Pedagogi dan Praktik dalam Pengajaran Bahasa Kedua, New York: Cambridge University Press. 23-37.

Ballard, KK (2006). Menggunakan model van manens untuk menilai tingkat reflektifitas di antara guru pendidikan jasmani pra-jabatan. Ahli filosofi. Universitas Negeri Tarleton

Behzadpour, F. (2007). Mengembangkan alat ukur untuk pengajaran reflektif. (Tesis master tidak diterbitkan). Universitas Tarbiat Modares, Teheran, Iran.

DeWalt, KM, \& DeWalt, BR (2002). Pengamatan partisipan: panduan bagi pekerja lapangan. Walnut Creek, CA: Alta Mira Press. 
Seminar Nasional Penelitian dan Pengabdian kepada Masyarakat

Universitas Sang Bumi Ruwa Jurai Tahun 2020

Farrell, TSC (2015). Mempromosikan refleksi guru dalam pendidikan bahasa kedua: Sebuah kerangka kerja untuk para profesional TESOL. New York, NY: Routledge.

Ferdowsi, M. \& Afghari, A (2015). Pengaruh pengajaran reflektif pada kinerja guru. Jurnal Internasional Investigasi Pendidikan. 2 (6). 20-31. 2410-3446.

Gay, L. R \& Peter, A. (2000). Kompetensi Riset Pendidikan untuk Analisis dan Aplikasi. PrenticeHall, Inc.

Gheith, E., \& Nahil, A (2018) Praktik pengajaran reflektif pada guru dan sikap mereka terhadap pengembangan diri profesional. Jurnal Internasional Pendidikan Progresif, 14 (3).

Goodley, C. (2018). Merefleksikan menjadi guru yang efektif di era pengukuran. Praktek Reflektif, 19 (1). 167-178.

Gross, EA (2014). Peran refleksi dalam instruksi guru ahli. Disertasi Universitas Negeri Wayne. Makalah 1073.

Harmer, J. (2007). Bagaimana Mengajar Bahasa Inggris. Cina: Pearson Education Limited.

Jay, JK (2003). Pengajaran berkualitas: Refleksi sebagai inti dari praktik. Lanham, MD: Scarecrow Press.

Mathew, P., Mathew, P., Prince, JP, (2017) Praktik Reflektif: Sarana Untuk Pengembangan Guru. Asia Pasifik Jurnal Pendidikan Kontemporer dan Teknologi Komunikasi (APJCECT). 3 (1). 2205-6181. www.apiar.org.au.

Moleong, LJ (2006). Metode Penelitian Kualitatif. Bandung: PT Remaja Rosdakarya.

Olaya, MML (2018). Pengajaran reflektif: Pendekatan untuk memperkaya praktik profesional

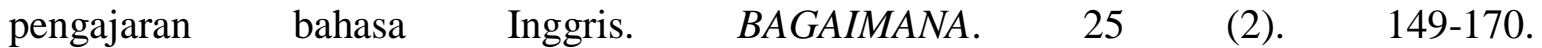
https://doi.org/10.19183/how.25.2.386.

Robichaux, RR \& Guarino AJ (2012). Meningkatkan Profesionalisme Guru Pra-jabatan melalui Refleksi Mengajar Harian. Penelitian Pendidikan Internasional. http://dx.doi.org/10.1155/2012/452687

Rose, M. (2007). Praktisi reflektif. Pusat Eropa untuk Bahasa Modern. Diperoleh pada September 2019 dari <http://www.ecml.at/html/quality/english/continuum/ self_assessement / teacher / MR_reflective\% 20practitioner.html.

Shandomo, HM (2008) Peran Refleksi Kritis dalam Pendidikan Guru. Buffalo State College. Kemitraan Sekolah-Universitas Vol. 4, No. 1

Subroto, E. (2007). Pengantar Metode Penelitian Linguistik Struktural. Surakarta: Lembaga Pengembangan Pendidikan Universitas Sebelas Maret. 
Seminar Nasional Penelitian dan Pengabdian kepada Masyarakat Universitas Sang Bumi Ruwa Jurai Tahun 2020 